\title{
ATTAINMENT OF CUSTOMER'S SATISFACTION IN DIGITAL FOOD APPS INDUSTRY THROUGH RESULT-ORIENTED MANAGEMENT
}

\author{
Deepa Singh \\ Research Scholar, MRIIRS, Faridabad, Haryana, India \\ Dr. Meghna Chhabra \\ Associate Professor, FMS- MRIIRS, Faridabad, Haryana, India
}

\begin{abstract}
In today's scenario of business, there is huge competition in business. Though there are increased business opportunities because of globalization but still it lead to much complexities in monitoring the workforce's performance. Food delivery apps are not just cutting our human-to-human contacts while delivery but also introducing us to try new restaurants and foods. We just simply enter our location and these apps show us thousands of restaurants that we can try without leaving our recliner or couch. We came across our favourite food delivery apps that bring yumminess and deliciousness rights to our door-steps.

Digital Food Apps Services are basically the designed websites primarily used in food delivery industries. These apps help restaurants to reduce their manpower costs and increasing their scope of business and making a profit. With just a few clicks of fingers, customers can browse and place their orders of choice from the nearby restaurants. This study aims to analyse that how food buying preferences have been changed by customers by using internet and to identify their related factors which are associated with them and how consumers are concerned for food safety information of online food items.

Customer-Satisfaction is basically the subject of how an individual, group of people or organizations choose, take, use and dispose of ideas, products, and services to satisfy their requirements and needs. It says about the activity of the customers in the market areas and the motives which are underlying for their activities.

This research study must focus on the move of customer's perceptions with the evolvement of technologies and the various types of apps that consumers are contented with and which makes them smiling about that particular facility. The primary objectives of this report are to know the relationship among the provided services and the buying nature of the consumer. Next is to discover out the most accepted apps in the
\end{abstract}


food transporting industries and to know how technologies have created a vital task in food industries.

Result-oriented management is a tool which makes employee's more motivated and productive by improving their competencies and skills. It is the systematic process of monitoring and supervising the role of employee so that they can achieve the organizational objectives in most efficient and effective ways. For example, now a days in digital food apps service, performance management of employees are priotized and hence many customers are ordering food online. This way, companies are also making profit In India, the market-size of food is predicted to succeed in Rs. 42.00 lakh crores by the year 2020, as BCG reports. The Indian foodstuff is around $\$ 350.00$ billion presently.

Happiness is the psychological state of well-being categorized by enjoyable and beneficial feeling ranges from satisfaction to extreme containment. To be happy at work place, it is important to give support and vice-versa from our colleagues. By helping others, we are more connected to them and are happier.

The four major pointers of result-oriented management in this modern globalized business scenario are: mutual understanding, procedural integrity, respect for employees and transparent decision -making. The five major components of performance management are: Result-oriented planning, understanding the expectations of customers, feed-back and coaching, rewarding good performer, and plans for performance improvement.

Key words: digital food apps; globalization; business scenario; result-oriented management; customer's satisfaction.

Cite this Article: Deepa Singh and Meghna Chhabra, Attainment of Customer's Satisfaction in Digital Food Apps Industry Through Result-Oriented Management, International Journal of Management, 11(12), 2020, pp. 2527-2543.

http://iaeme.com/Home/issue/IJM?Volume=11\&Issue=12

\section{INTRODUCTION}

A report from Red Seer Consulting says that there is a strong growth rate in the number of daily orders in India's online food ordering sector, which is growing at consistent rate of $15 \%$ quarterly from January to September in the year 2017. During the September quarter, the rise in the number of orders on daily basis hit an average of 400,000.This gave rise to the players like Zomato, Swiggy and Food panda which are investing in in-sourcing deliveries. The selfdeliveries grew to $56 \%$ of the total number of orders done by the digital food apps sector in India as reported in September quarter. The self-deliveries remained at $46 \%$ in the last quarter of the year 2016. In past, eating in restaurants were not an eminent features for any individual or groups in India but as time passes, eating in restaurants has obtained the driving power due to the fluctuating patterns of consuming foods. This pattern of fluctuation gave rise to the foodservice industries in the country like India. The food service markets of India have covered a distant of miles if compared with the early eighties when popular names were countable on fingers and unstructured participants influenced the market. The apparent change in food market came in the year 1996 with commencement of many restaurants like Domino's, Pizza Hut and Mc Donald's accompanied by Barbeque Nations, Haldiram's, Subway, Moti- Mahal, etc. From the past few years, there has been a proliferate growth in the counts of food start-ups. As BCG reports that the market -size of Indian food industries is assumed to outstretch to Rs.42 lakh crore by the year 2020. The current scenario of food market in India is almost Rs.23 trillion. The online food delivery industries of India faced much barriers at the growth-stage in the year 
2016 with many of the other players which are curtailing its operations and closing their shops. This was seen in low shareholders opinion and on the other hand as reported by Red Seer, industries gave the result of total finance of lesser than 80.0 million US $\$$ in the year 2016 towards 500.0 million US $\$$ before the same session year.

The online policy have eased the customer's life by helping them to increase their reach by opting for many options offered by online policy in place of ordering food by just giving call to individual restaurants. The allocation of online food transportation for committee restaurants (restaurants related to on-line delivery platforms) coated during a learning done by Red Seer has arrived at $30 \%$ to $35 \%$ of their entire business and these numbers appear to be expanding apace on each successive day.

Apps square measure providing redoubled facilities and services to the consumers to match up with the consumer's expectations. The following situation doesn't survive solely in single country however in entire world. Referring till now with the customers' presumption helps the firm hang on to customers to a larger proportions.

The growth has started in the digital technology, it can still expand at a fast rate and because of the impact of this thus will the assorted different food industries, together with the delivery of food business. Within the given table and figure below, we see that the use of online web portals is perpetually growing and that are estimated to extend at a fast rate even in coming days. Our analysis indicates that on-line food penetration of the entire delivery of food market skint $30.00 \%$ in the year 2016. It's conjointly accepted that the penetration rates can expand any because the market of food matures, eventually reaching $65.00 \%$ annually. According to the different analysis, the user's perceptions relating to the quality of service of ZOMATO is a smaller amount than its expectations of a wonderful service ought to be. Thus, ZOMATO can't be classified as a wonderful service supplier as of the responses given by the users.

In GDP, the service or system sector contributes $64.81 \%$ in today's scenario. Zomato is among in every of the foremost standard apps which offer services to the utilizers to get restaurants. The reshaping of the industries is because of the increase in digital technology. The quantity of individuals partaking within the digital sector is apace growing with the redoubled use of technology. Customers even square measure familiar with searching or perhaps ordering on-line through websites or apps, with the most transparency and convenience, looking for equivalent expertise that they'd get from the outlet.

Table 1 Online /Mobile Ordering vs. Offline Ordering.

(Data gathered from Cowen and Company Research)

\begin{tabular}{|c|c|c|}
\hline Year & Online /Mobile Food Ordering Percentage & Offline Food Ordering Percentage \\
\hline 2012 & $13 \%$ & $87 \%$ \\
\hline 2014 & $22 \%$ & $78 \%$ \\
\hline 2016 & $30 \%$ & $70 \%$ \\
\hline 2018 & $38 \%$ & $62 \%$ \\
\hline 2020 & $47 \%$ & $53 \%$ \\
\hline 2022 & $51 \%$ & $49 \%$ \\
\hline 2024 & $58 \%$ & $42 \%$ \\
\hline
\end{tabular}




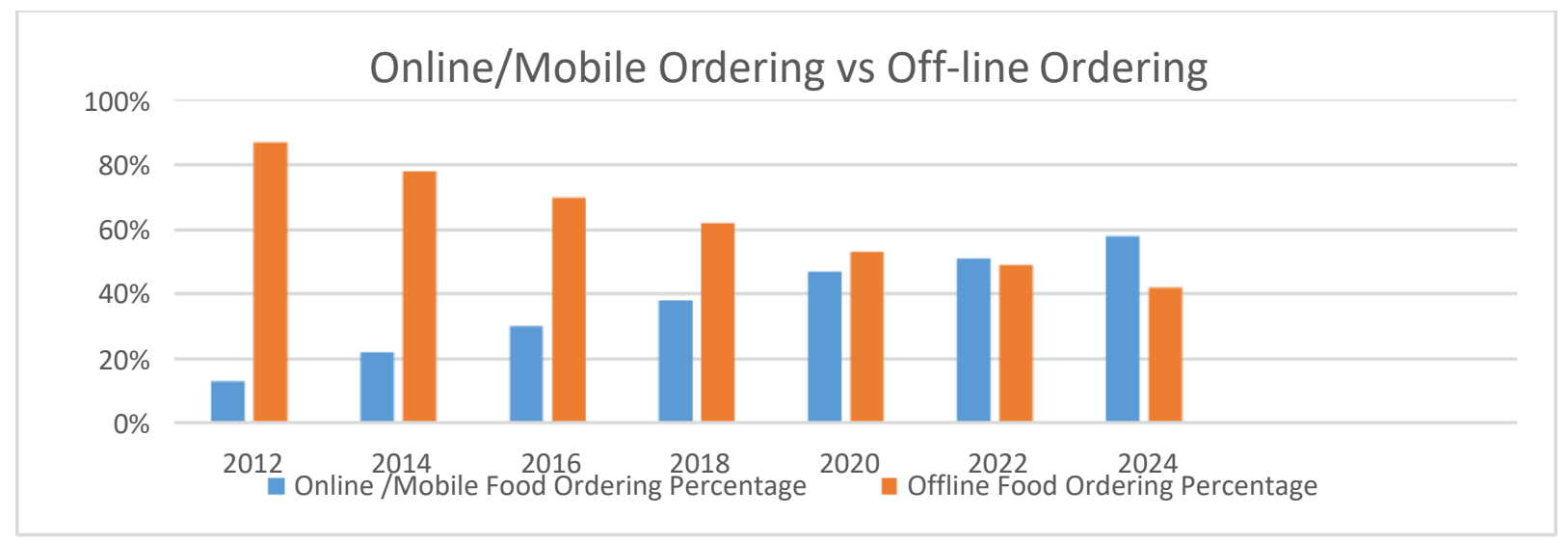

Figure 1 Online ordering vs off-line ordering.

The innovations which are recent within the markets around the world are

- IPad ordering kiosks.

- Mobile ordering.

- Work surface e-waiter \& checkout.

- Online coupons.

- Games while-once-wait.

- Digital food menu boards and smartphones

Varied apps within the Indian market are

- Zomato

- Swiggy

- Food Panda

- Box 8

- Fasoos

- Uber Eats

As per the report in business standard (January, 28, 2020), the growth in online buyers and their spending capability because of rapid digitisation must help the online food industry in India become 8 billion $\$$ market by the year 2022 which results the CAGR growth of $25-30 \%$. The variety in food cuisines (35\%) followed by the proper convenience and discounts are the top reasons for repetitive use of online food ordering apps as per the report by Boston Consulting Group and Google.

Food industries have touched 500 cities in India where customer confidence is growing after each passing days. There are great chances for the food players to win the customers in this growing market. The overall spending in online food in India is rising at fast pace which is recorded to grow by $25 \%$ over the next 5 years and must reach over by 130 billion $\$$.

Currently in India, Zomato and Swiggy are dominating the online food delivery industries. The last week, Zomato announced that it acquired Uber Eats in India in an overall deal of nearly 350 billion $\$$ and Uber Eats had a stake of $9.99 \%$ in the Deepinder Goyal- led food delivery platform.

As per the report of Business Standard (February 28, 2020), Jeff Bezos teams up with the Infosys CEO Narayan Murthy to enter in the Food delivery market in India. The day Zomato and Swiggy started cutting back on the discounts, Amazon started entering in the business of food delivery. 
The last month itself, Bezos told the audience in Amazon event held in New Delhi that the Amazon is planning to invest 1 billion \$ in India. In the coming month, Amazon must take the established players such as Swiggy and Zomato. Further the report in Dainik Bhaskar says that the pilot testing about its service has been already stated in Bengaluru's selected parts by the ecommerce giants.

In the study done further, we see that most of the respondents prefer online food ordering over not ordering food online. Out of 200 respondents, 174 respondents order food online while 26 respondents don't order food online.

Further we see that, most of the respondents prefers Swiggy for online food delivery which results to be 79 respondents who showed their choice for ordering food through Swiggy then comes Zomato with 43 respondents, then Food panda with 38 respondents, Uber Eats 15 and who didn't order from online food delivery apps are 25 respondents.

Different respondents have different criteria of ordering foods. Some orders almost daily, while others order weekly, monthly or fortnight. Generally, we see that respondents order weekly and monthly more which results to be 59 and 53 in numbers.

Further we see that, there is significant relation between the factors affecting the attitudes and the choice of facilities provided for online food.

We see that there are many customers who are extremely unhappy after taste which are being ordered which makes it one of the great challenge to improve to retain customers for online food.

\section{LITERATURE REVIEW}

The Walker Consulting (2020) predicts that apart from the product and price itself, the customer experience and the customer satisfaction provided proves to be the key differentiator.

In Digital Trends report (2018), the e-consultancy showed the most exciting business opportunity are Customer Experience (22\%), Content Marketing (15\%), Mobile (13\%), Personalization (11\%) and the Social (7\%).Thus from customer experience comes the customer's satisfaction which is at the topmost among the business opportunities.

As per Online Food Delivery- A Red Seer Perspective (February, 2017), the restaurant industries are estimated to be 56 Billion USD and the delivery industries are being pegged at 15 Billion USD. The major factors which are driving in the growth in delivery are the fluctuating customer's life-style, the youngsters, growth in disposable income and the high share of women in the work-force as mentioned by Key Insights (2016). In the business model comparison among the aggregators and internet kitchen with the key metrics like menu, foodquality, average order value, capital requirement, expansion to new geographies and key players; aggregator's market-share is $70 \%$ and that of internet kitchen is $30 \%$ as mentioned in Key Insights (2017).

As per the study of Zulkarnain Kedah and et al. (January, 2016), the customer ordering experience determinants include the customer satisfaction, the trust on website and the customer's loyalty. There are significant positive relationship between the customer satisfaction and the service quality. The significant positive result are found between the customer satisfaction and the customer's loyalty too. The study found the direct link between the quality of service and loyalty of customers. Deepinder Goyal, Zomato corporate executive and co-founder (2015) told that Tech Crunch expects to succeed ten thousand restaurants in a very few months in India. "We have a sales team of around 300 in India and 5,000-odd advertisers. These partners apprehend the amount we tend to wake up them therefore it's quite simple for North American country to launch this new service." in keeping with a current divisional report revealed by Indian whole Equity Foundation (IBEF), the food has been there 
in every of the biggest divisions in Indian retail sector, estimated $\$ 490.00$ billion in the year 2013. The food retail market is anticipated to grow $\$ 894.98$ billion (Rs. 61 lakh crores) by the year 2020 in India.

The Gloria Food discussed on-line food ordering and the reasons for the food delivery apps growth are simple menu to manage, extra savings, zero hassle and convenience, etc. According to Shiyin Chan (2015), Food Panda is Associate in Nursing introduction to the most recent food sensation that's here to remain. Food Panda headquartered in Berlin, Germany could be on-line food delivery marketplace in the world. The fun truth - they're additionally called greeting food in different places within the entire world.

According to S. Bhavna (2015), Food panda is a gift within the Indian market since the year 2012. Food panda's starting important move was a sale of Tasty Khana, which was inaugurated within the town of Pune in the year 2007. In conjunction with Tasty Khana and simply, it's a current gift in over two hundred cities and participants with over twelve thousand restaurants. She additionally said concerning Just Eat which was inaugurated in the Scandinavian country in the year 2001 and was listed on the London exchange publically. The Indian business was inaugurated as a Hungry urban center in the year 2006. It had been again named in the year 2011 once simply EAT no heritable a maximum share within the business. Now a days, it is corporate partners with over two thousand restaurants.

Morley and Parker (2010), secondary knowledge authors acknowledged that on-line merchandising in its many forms, together with food merchandising and grocery product area unit thought of to be an element of electronic commerce. The e-commerce will be outlined: "conducting business transactions - usually money transactions - via communications technology". Laudon and Traver (2009) that the web boom generally, and the electronic commerce above all has started towards the end of the last century had reworked the varied lives aspects of individuals considerably on a worldwide parameters. Hall (2008) mentions in a survey conducted in year 2008, which disclosed that $65 \%$ of the food corporations were busy in marketing food specialty through the web. As Gustafson (2006) said that authors provide completely dissimilar perspective concerning the character of that result however acknowledge on the thought that "with the introduction of e-commerce, we've got come back to expect 24hour delivery of product from across the globe, and residential delivery of groceries from the native Tesco at a time of our choosing".

Kornum \& Bjerre (2005) informed that "one of the most issues of e-commerce within the grocery sector is that solely only a few companies can create a profit. So it's necessary to spot the most price drivers of the business and address the question of a way to balance the requirements expressed by customers and also the resources utilized by a firm as a consequence of those generated needs".

Graham (2004) expressed that "a fascinating facet of the huge growth of food e-commerce has been the emergence of the good of business models through that retailers decide to organize the delivery of services". Generally, there are unit 3 techniques during which the food delivery and grocery product is being organized by corporations. First of all, there area unit corporations as Tesco United Nations agency that organize the delivery of the product to on-line consumers from the highest offline sub-divisions of the shop. Secondly, additional corporations opt to organize the transportation from unique designed store-houses. Thirdly, many others have selected to source the transportation operate of their business to 3rd associations. May (2000), Kozami (2002), Ashley (2004) and others denied the thought that buying grocery and food products through the website is a completely new factor. They justified their base by mentioning that "we ought to be suspicious of claims that net provisioning a few things entirely new. Their area unit obvious continuities with existing phone and tv looking, even though the service has become widespread and notionally democratized". 


\section{DESCRIPTION OF BROAD AREA}

As Zomato, Swiggy and Food panda are among the top food ordering and delivery firms which are giving huge discounts and data obfuscation are prevailing in them which comes as a great concerns for the NRAI (National Restaurant Association of India) as reported by the Press Trust of India (January, 8,2019). In the meeting held with online food delivery industries, the NRAI said that these mentioned delivery firms has indicated issues regarding dominant position misapply. The concern for the meeting was to talk upon the huge discount, data obfuscation, use of own logistics right, the private labels and the ad hoc campaigns. This was the first meeting (January, 2019) with the mentioned delivery firms and the president of NRAI- Rahul Singh. It was discussed in the meeting that the concerns were taken in the well manner and the meetings will be aimed to continue on a bi-monthly basis for discussion of the feedbacks from the food industry to the aggregators to ensure that stakeholders must have healthy business environments.

As per Neha Alawadhi (March 3, 2020), Uber Eats was sold to Zomato for 206 million \$ (includes the investment valued at 171 million $\$$ and goods reimbursement and service tax at 35 million \$) which was said by the US- based firm in its annual report which was filed with the Exchange Commission and US Securities. The deal done on January 21, 2020 confirmed that Uber must get $9.9 \%$ stake in Zomato. The deal at that time seems to reach 350-400 million $\$$. Uber Eats didn't report its sale as a discontinued operations but reported that now it must not be a big player in food delivery chains.

There are great changes in customer's behaviour which are regularly seen by internet -led businesses. The huge transformation is made in the way most of the households cook and eat foods by offering them varieties, affordability and convenience to drive the change in their behaviour. The two brands like Zomato and Swiggy have marked the territory out between themselves by making a box of tools to sharpen their engagement and keep their customers loyal to them (February 24, 2020).

As per Peerzada Abrar \& Neha Alawadhi (February 20, 2020), Swiggy has raised 113 million $\$$ as per Series-1 Funding. The valuation of Swiggy was 3.3 billion $\$$ presently and its previous valuation was 1 billion $\$$ in recorded in December, 2018.

The parent company of Swiggy i.e. Bundl Technologies raised 112 million $\$$ from Naspers which is the South African conglomerate and other existing investors. As per the regulatory documents filed by Swiggy which are being sourced from Paper.ve which is the business signals platform, the Naspers is the largest shareholder in Swiggy with $40.56 \%$ of holding completely. Swiggy is planning to invest upto 1 billion $\$$ for its delivery of foods and business of cloud kitchen. Swiggy remained at the same level of 3.3 billion $\$$ as per the Naspers along with other investors like Hill house Capital, China's Tencent and the Wellington Management Company. Swiggy is competing with Zomato and few smaller and rapidly growing cloud kitchens businesses like Rebel Foods and Box8 as per Peerzada Abrar (February 20, 2020).

The biggest challenge for the food delivery industries are the profitability. The net loss of Rs. 2,346 crore in the financial year 2018-19 was there as reported by Swiggy. As per data platform Tofler, this loss was an increase of over 5 times over the last financial year. The company revenue has risen up to 183 times still calculating Rs. 1,292 crore. The overall expenses for the fiscal are still high calculating Rs. 3,638 crore which remained the reason to increase in employee expenses, delivery costs and the advertising expenses.

Food panda being owned by the ride-hailing giant Ola reported a net loss of Rs. 756 crore in the fiscal year 2019. This loss rate of Rs. 756 crore was one of the biggest among the Indian start-ups on revenue of Rs. 82 crore. 


\section{OBJECTIVES OF RESEARCH}

- To examine the position of food delivery apps service in terms of market-share in Faridabad, Delhi and Ghaziabad.

- To analyze factors affecting the attitude of customers (perceptions and preferences) regarding food delivery apps and do a customer satisfaction analysis in Delhi and NCR.

- To analyze the encountered challenges in online food opting from the customer's perspective.

\section{METHODOLOGY}

First of all, the different electronic databases like Google Scholar, EBSCO, Science Direct, ProQuest and Scopus are used in order to address the objectives of the research study and the literature review has been conducted for the attainment of customer- satisfaction in digital food apps services through result- oriented management. In order to study on the selected factors, 200 responses using the sampling techniques like random and convenient ensuring respondents from different back-ground and experience- level.

The quantitative analysis was supported by primary information collected once the by online and hand distribution of an appropriate questionnaire-form.

The analysis should come about in Delhi and NCR specifically Faridabad, Delhi and Ghaziabad etc.

The survey questionnaires with 17 questions were filled by different groups of people in the mentioned areas. The questionnaires were related to the frequencies of online orders, choice of food- delivery apps, factors affecting the attitude of customers (perceptions and preferences), customer satisfaction level analysis, analysis of encountered challenges in opting online food from the customer's perspective.

\section{INTERPRETATIONS}

In order to understand the behaviour of the customers regarding using of online food delivery apps, some of the characteristics of the respondents are studied as they proves to be the important variables to decide the consumption patterns and behaviour of the respondents regarding the apps being studied in this research. The following table no. 2 represents the socioeconomic pattern of the respondents.

To validate different objectives, different questions from the questionnaires were studied:

Objective 1: To examine the position of food delivery apps service in terms of market share in Faridabad, Delhi and Ghaziabad.

We used descriptive analysis and weighted percentage to validate this objective. Question no. 1, 2, 3 and 6 have been considered to proof this objective.

In table-3, we see respondents who prefer online food delivery apps vs who didn't prefer online food delivery apps. In the table we see that 174 respondents order food online while 26 respondents don't order food online. 
Table 2 Demographic profile (Source: Primary Data)

\begin{tabular}{|c|c|c|c|}
\hline Category & Description & Numbers & Percentage \\
\hline Genders & MALE & 109 & $54 \%$ \\
\hline & FEMALE & 91 & $45 \%$ \\
\hline & TOTAL & $\mathbf{2 0 0}$ & $\mathbf{1 0 0 \%}$ \\
\hline Address & DELHI & 64 & $31.70 \%$ \\
\hline & FARIDABAD & 63 & $31.20 \%$ \\
\hline & GHAZIABAD & 73 & $36.10 \%$ \\
\hline $\begin{array}{c}\text { Money spent } \\
\text { on ordering } \\
\text { food }\end{array}$ & TOTAL & $\mathbf{2 0 0}$ & $\mathbf{1 0 0 \%}$ \\
\hline & $<$ Rs. 150 & 28 & $13.60 \%$ \\
\hline & $<$ Rs. 250 & 76 & $38.20 \%$ \\
\hline & $<$ Rs. 500 & 59 & $29.60 \%$ \\
\hline & $>$ Rs. 500 & 37 & $18.60 \%$ \\
\hline Age of people & TOTAL & $\mathbf{2 0 0}$ & $\mathbf{1 0 0 \%}$ \\
\hline & $20-30$ Years & 25 & $12.50 \%$ \\
\hline & $30-40$ Years & 41 & $20.50 \%$ \\
\hline & $40-50$ Years & 37 & $34.50 \%$ \\
\hline & $50-60$ Years & 27 & $18.50 \%$ \\
\hline & TOTAL & $\mathbf{2 0 0}$ & $\mathbf{1 0 0 \%}$ \\
\hline & & & \\
\hline
\end{tabular}

Table 3 Ordering online vs not ordering online.

\begin{tabular}{|c|c|c|c|c|c|}
\hline \multicolumn{6}{|c|}{ Do you order food online? } \\
\hline & & Frequency & Percent & Valid Percent & $\begin{array}{c}\text { Cumulative } \\
\text { Percent }\end{array}$ \\
\hline \multirow[t]{4}{*}{ Valid } & & 3 & 1.5 & 1.5 & 1.5 \\
\hline & YES & 174 & 85.7 & 85.7 & 87.2 \\
\hline & NO & 26 & 12.8 & 12.8 & 100.0 \\
\hline & Total & 203 & 100.0 & 100.0 & \\
\hline
\end{tabular}

We see in the below table-4, we see that most of the respondents prefers Swiggy for online food delivery which results to be 79 respondents who showed their choice for ordering food through Swiggy then comes Zomato with 43 respondents, then Foodpanda with 38 respondents, Uber Eats 15 and who didn't order from online food delivery apps are 25 respondents.

Table 4 Preference for online food delivery apps

\begin{tabular}{|c|c|c|c|c|c|}
\hline \multicolumn{6}{|c|}{ If yes, then from which delivery apps you prefer? } \\
\hline \multirow{2}{*}{} & Frequency & Percent & Valid Percent & Cumulative Percent \\
\hline \multirow{4}{*}{} & & 3 & 1.5 & 1.5 & 1.5 \\
\cline { 2 - 6 } & ZOlid & 43 & 21.2 & 21.2 & 22.7 \\
\cline { 2 - 6 } & SWIGGY & 79 & 38.9 & 38.9 & 61.6 \\
\cline { 2 - 6 } & FOODPANDA & 38 & 18.7 & 18.7 & 80.3 \\
\hline
\end{tabular}




\begin{tabular}{|c|c|c|c|c|}
\hline UBER EATS & 15 & 7.4 & 7.4 & 87.7 \\
\hline $\begin{array}{c}\text { NONE OF THE } \\
\text { ABOVE }\end{array}$ & 25 & 12.3 & 12.3 & 100.0 \\
\hline Total & 203 & 100.0 & 100.0 & \\
\hline
\end{tabular}

\section{If yes, then from which delivery apps you prefer?}

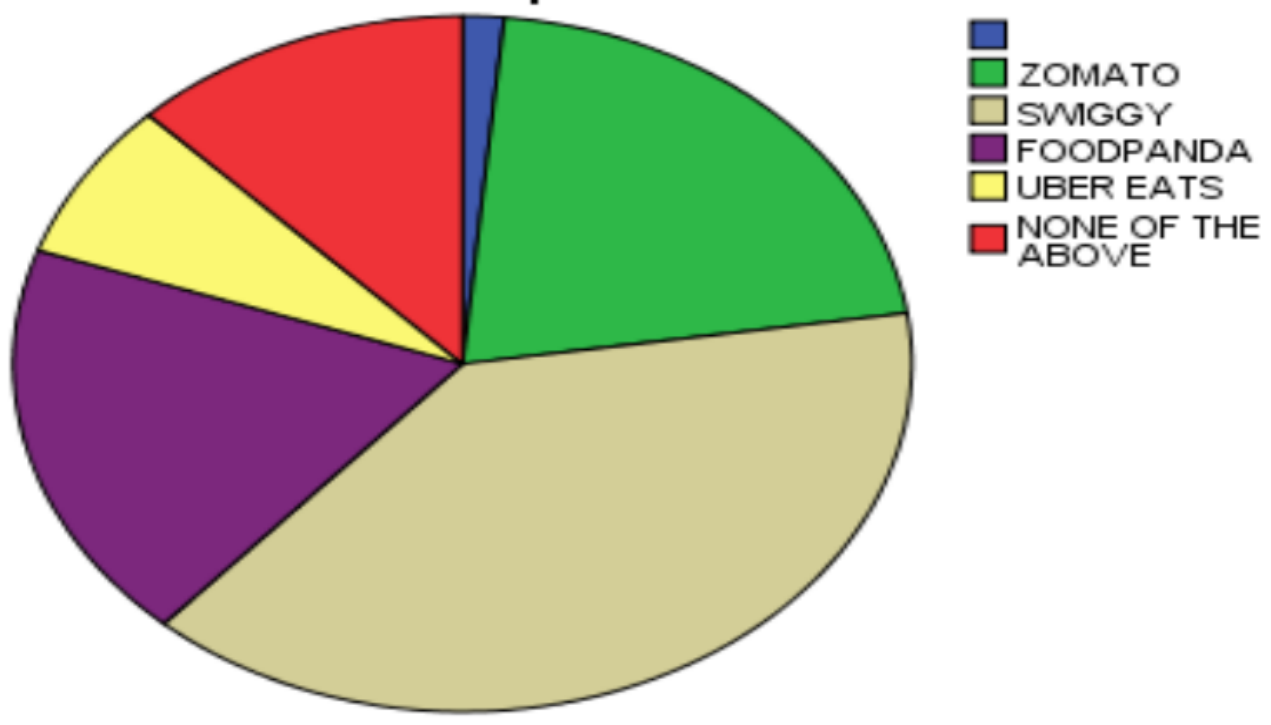

Figure 2 Pie -chart for preference of online food delivery apps

We see in below table-5, different respondents have different criteria of ordering foods. Some orders almost daily, while others order weekly, monthly or fortnight. Generally, we see that respondents order weekly and monthly more which results to be 59 and 53 in numbers.

Table 5 Frequencies of food ordering.

\begin{tabular}{|c|c|c|c|c|c|}
\hline \multicolumn{6}{|c|}{ How often you order food online? } \\
\hline \multicolumn{1}{|c|}{} & Frequency & Percent & Valid Percent & $\begin{array}{c}\text { Cumulative } \\
\text { Percent }\end{array}$ \\
\hline \multirow{7}{*}{} & & 3 & 1.5 & 1.5 & 1.5 \\
\cline { 2 - 6 } & - & 21 & 10.3 & 10.3 & 11.8 \\
\cline { 2 - 6 } & $\begin{array}{c}\text { ALMOST } \\
\text { VAlid }\end{array}$ & 39 & 19.2 & 19.2 & 31.0 \\
\cline { 2 - 6 } & WEILY & 59 & 29.1 & 29.1 & 60.1 \\
\cline { 2 - 6 } & WEKLY & 53 & 26.1 & 26.1 & 86.2 \\
\cline { 2 - 6 } & MONTHLY & 28 & 13.8 & 13.8 & 100.0 \\
\cline { 2 - 6 } & FORTNIGHT & 203 & 100.0 & 100.0 & \\
\hline
\end{tabular}

Generally, respondents goes for ordering food each time for less than Rs. 250 which is 76 in numbers and less than Rs.500 which is 59 in numbers. 
Table 6 Approximate money spent each time of order.

\begin{tabular}{|c|c|c|c|c|c|}
\hline \multicolumn{6}{|c|}{ What is the approximate money you spend to ordering food per time? } \\
\hline \multirow{4}{*}{} & Frequency & Percent & Valid Percent & $\begin{array}{c}\text { Cumulative } \\
\text { Percent }\end{array}$ \\
\hline \multirow{4}{*}{ Valid } & $<$ Rs.150 & 27 & 13.3 & 13.6 & 13.6 \\
\cline { 2 - 6 } & $<$ Rs.250 & 76 & 37.4 & 38.2 & 51.8 \\
\cline { 2 - 6 } & & & & & \\
\cline { 2 - 6 } & & & & & \\
\cline { 2 - 6 } & $<$ Rs.500 & 59 & 29.1 & 29.6 & 81.4 \\
\cline { 2 - 6 } & $>$ Rs.500 & 37 & 18.2 & 18.6 & 100.0 \\
\cline { 2 - 6 } & Total & 199 & 98.0 & 100.0 & \\
\hline \multirow{3}{*}{ Missing } & System & 4 & 2.0 & & \\
\hline \multicolumn{2}{|c|}{ Total } & 203 & 100.0 & & \\
\hline
\end{tabular}

Objective-2: To analyse factors affecting the attitude of customers (perceptions and preferences) regarding food delivery apps and do a customer satisfaction analysis in Delhi and NCR.

To validate this objective, we used Chi-square test and check hypothesis. Question no.- 7 have been considered to proof this objective.

Table 7 Table for Observed value.

\begin{tabular}{|c|c|c|c|c|c|c|c|}
\hline \multicolumn{2}{|c|}{$\begin{array}{c}\text { Table of Observed Values } \\
\begin{array}{|c|}\text { Factors affecting attitudes/ } \\
\text { choice of facilities provided } \\
\text { for foods }\end{array}\end{array}$} & Strongly Disagree & Disagree & Neutral & Agree & Strongly Agree & TOTAL \\
\hline On-base Restaurants & 69 & 52 & 20 & 36 & 23 & 200 \\
\hline Service Quality & 20 & 32 & 38 & 67 & 43 & 200 \\
\hline Price & 12 & 42 & 26 & 34 & 86 & 200 \\
\hline Menu & 16 & 46 & 39 & 77 & 22 & 200 \\
\hline Appearance of delivery person & 59 & 12 & 70 & 38 & 21 & 200 \\
\hline Quality of food -delivered & 35 & 28 & 9 & 82 & 46 & 200 \\
\hline TOTAL & 211 & 212 & 202 & 334 & 241 & 1200 \\
\hline
\end{tabular}

\section{Observed Value}

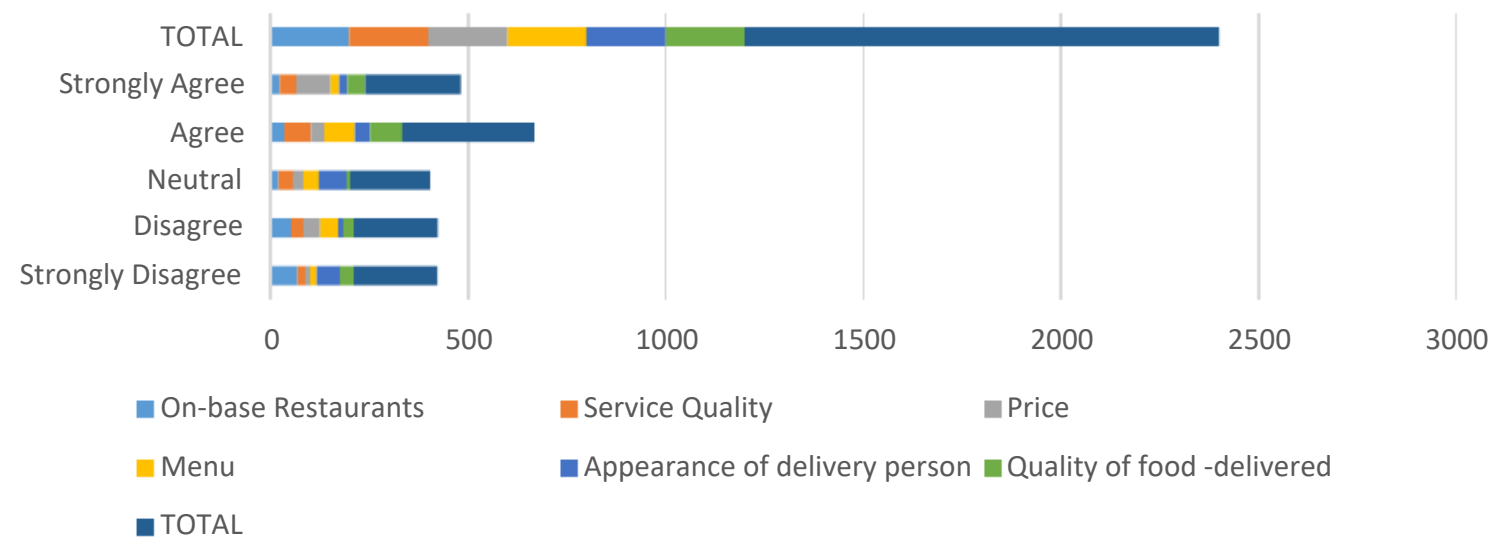

Figure 3 Observed Value 
After calculating the expected/ calculated value, we find out the chi-square value (calculated) which came 298.41.

Degree of freedom, $\mathrm{df}=($ column- $)($ row- 1$)=(6-1)(5-1)=5 * 4=20$

Significance Level (alpha) $=0.05$

Chi-square $($ Tabular $)=31.41$

Chi-square $($ Calculated $)=298.41$

Therefore, we reject null hypothesis (Ho), and accept alternate hypothesis (H1); i.e. there is significant relation between the factors affecting the attitudes and the choice of facilities provided for online food.

Objective-3: To analyse the encountered challenges in online food opting from the customer's perspective.

The descriptive analysis has been done to validate this objective. Question no.- 12 has been considered to proof this.

One of the challenges in online food opting is the taste of food. Though, many of them finds food to be tasty but still there are some respondents who finds it untasty and usual type of food which needs to be work out for high demand of on-line food other customer may not go for online foods,

Table 8 Frequencies for ordering food on the basis of taste.

\begin{tabular}{|c|c|c|c|c|c|}
\hline \multicolumn{6}{|c|}{ How do you find the taste of food which are being ordered online? } \\
\hline & & Frequency & Percent & Valid Percent & $\begin{array}{c}\text { Cumulative } \\
\text { Percent }\end{array}$ \\
\hline \multirow{5}{*}{ Valid } & VERY TASTY & 42 & 20.7 & 21.0 & 21.0 \\
\hline & TASTY & 84 & 41.4 & 42.0 & 63.0 \\
\hline & UNTASTY & 26 & 12.8 & 13.0 & 76.0 \\
\hline & $\begin{array}{l}\text { NEITHER TOO TASTY } \\
\text { NOR TOO UNTASTY }\end{array}$ & 48 & 23.6 & 24.0 & 100.0 \\
\hline & Total & 200 & 98.5 & 100.0 & \\
\hline Missing & System & 3 & 1.5 & & \\
\hline & Total & 203 & 100.0 & & \\
\hline
\end{tabular}

We see that there are many customers who are extremely unhappy after taste which are being ordered which makes it one of the great challenge to improve to retain customers for online food.

Table 9 Frequencies of happiness after food taste.

How happy are you with your delivered order after taste and the food which are being ordered before taste?

\begin{tabular}{|c|c|c|c|c|c|}
\hline \multicolumn{2}{|c|}{} & Frequency & Percent & Valid Percent & $\begin{array}{c}\text { Cumulative } \\
\text { Percent }\end{array}$ \\
\hline \multirow{6}{*}{ Valid } & Extremely Unhappy & 5 & 2.5 & 2.5 & 2.5 \\
\cline { 2 - 6 } & 2 & 12 & 5.9 & 6.0 & 8.5 \\
\cline { 2 - 6 } & 3 & 10 & 4.9 & 5.0 & 13.5 \\
\cline { 2 - 6 } & 4 & 8 & 3.9 & 4.0 & 17.5 \\
\cline { 2 - 6 } & 5 & 12 & 5.9 & 6.0 & 23.5 \\
\cline { 2 - 6 } & 6 & 14 & 6.9 & 7.0 & 30.5 \\
\cline { 2 - 6 } & 7 & 25 & 12.3 & 12.5 & 43.0 \\
\hline
\end{tabular}




\begin{tabular}{|c|c|c|c|c|c|}
\hline \multirow{7}{*}{} & 8 & 42 & 20.7 & 21.0 & 64.0 \\
\cline { 2 - 6 } & 9 & 44 & 21.7 & 22.0 & 86.0 \\
\cline { 2 - 6 } & Extremely Happy & 28 & 13.8 & 14.0 & 100.0 \\
\cline { 2 - 6 } & Total & 200 & 98.5 & 100.0 & \\
\hline Missing & System & 3 & 1.5 & & \\
\hline \multicolumn{2}{|c|}{ Total } & 203 & 100.0 & & \\
\hline
\end{tabular}

The other challenge from the study is the quick delivery of food to retain brand loyalty and gain profits for the company, otherwise customer may switch from that particular online delivery apps.

Table 10 Speed of food-delivery by delivery boy to retain brand loyalty and gain profit.

\begin{tabular}{|c|c|c|c|c|c|}
\hline \multicolumn{6}{|c|}{$\begin{array}{l}\text { Did you think that delivery boy should deliver food quickly to customers to } \\
\text { retain brand-loyalty and gain profits to the company? }\end{array}$} \\
\hline & & Frequency & Percent & Valid Percent & $\begin{array}{l}\text { Cumulative } \\
\text { Percent }\end{array}$ \\
\hline \multirow{3}{*}{ Valid } & Not Agree & 98 & 48.3 & 49.0 & 49.0 \\
\hline & Mostly Agree & 102 & 50.2 & 51.0 & 100.0 \\
\hline & Total & 200 & 98.5 & 100.0 & \\
\hline Missing & System & 3 & 1.5 & & \\
\hline \multicolumn{2}{|c|}{ Total } & 203 & 100.0 & & \\
\hline
\end{tabular}

\section{KEY DRIVERS OF THE EXPANSION OF ON- LINE ORDERING OF FOOD IN INDIA AFTER RESEARCH STUDYMASSIVE PARTS OF THE YOUNGSTERS.}

- Improving incomes.

- Fluctuating customer's lifestyle- On-line ordering of food is straight forward means in present exaggerated life with the harassed routine.

- Growth in operating population of ladies in cities.

- Technology Expansion- Anywhere-anytime approachability.

- Suitable than house-made food and for consumption out.

- It's easier for purchasers to go to one marketplace web-site (or installing the app) rather than browsing websites (putting in apps) of each food-chain within the space.

- Because of the presence of the marketplace, customers have a lot of choices and it is much easier to find out all the restaurants \& cuisines obtainable within the space.

\section{CONCLUSION}

Swiggy is among the top-most food delivery firms in India if compared with Zomato and Food panda. Swiggy has two major business models:

- The major part of revenues which Swiggy collects from the commission comes from restaurants for generation of leads and serving as delivery partners.

- The nominal delivery charges from the customers are taken in most of the cities if the orders are below a threshold amount of Rs. 200 in most of the cities.

Swiggy is backed by the investor like Nasper in the market. Swiggy is generating 75.5 million $\$$ in funding many investors like Norwest Venture, SAIF Partners, Accel Partners, Bessemer Venture Partners, RB Investments, Apoletto and Harmony Venture Partners.

The Indian food delivery industries are valued at 15 billion $\$$ and are set to have growth exponentially. Swiggy had direct competition with the other major on- demand aggregators like 
Zomato and the other small start-ups like Foodpanda and Fassos which are also in the competition. With the regular rush of working executives in urban and speedy Indian urbanization prospects, the delivery of food and building phase is currently blooming at an intense rate. Summing to the current situation is an associate degree growing the variety of delivery food apps and smartphones. Food transporting apps have currently become a giant hit with people who are tech-savvy across Indian cities. There are many delivery food apps in the Indian market that 1 will transfer on smartphones to order food on the single go of finger and from the ease of their houses. The current research finds major link-ups between important factors that are considered necessary while choosing food delivery apps.

From the analysis drawn, a major relationship found between factors examined supreme while choosing a delivery food app. Electronic media ought to be the foremost desirable tool for promoting by corporations. Presently money after delivery is that the most popular possibility of transactions by the examinees however alternative electronic techniques are within the expansion stage. Industries should conjointly make certain that the apps are comfy and user-friendly. The unique apps are easy approaches for the consumers to put commands and for the industry to draw in more additional consumers however the ease of usage should tend a better fondness.

\section{RECOMMENDATIONS}

- Interestingly, these observations vary based on the maturity of the market. While delivery charges is the top reason for not ordering food online in metro cities; in Tier I cities, lack of trust in apps are the primary roadblock.

- They need to improve their loop-holes related to safety and hygiene of food in order to become catchier among customers.

- The customer faces many challenges if the site is slow or down. Thus, the owner of restaurant must know some techniques to place the order quickly and effectively.

\section{REFERENCES}

[1] Bhattacharjee, N. (2016, August 24). How FreshMenu plans to build a foodtech giant in India. Tech in Asia. Retrieved from https://www.techinasia.com/freshmenu-plans-growth.

[2] Bhargave, A., Jadhav, N., Joshi, A., Oke, P., \& Lahane, S.R. (2013). Digital Ordering System for Restaurant using Andriod. International Journal of Scientific and Research Publications, 3(4). pp 1-7.

[3] BS Web Team (2020), "Jeff Bezos teams up with Narayana Murthy to enter India's food delivery biz". Business Standard, February 28, 2020. Retrieved from https://www.businessstandard.com/article/companies/jeff-bezos-partners-narayana-murthy-to-enter-fooddelivery-biz-in-india-120022800111_1.html.

[4] Brady, M, K., Joseph C. Jr. (2001) Some New Thoughts on Conceptualizing Perceived Service Quality: A Hierarchical Approach. Journal of Marketing: July 2001, Vol. 65, No. 3, pp. 34-49.

[5] Canny, I. (2014). Measuring the mediating role of dining experience attributes on customer satisfaction and its impact on behavioral intentions of casual dining restaurant in Jakarta. International Journal of Innovation, Management and Technology, 5 (1), 25 - 29.

[6] Chavan, V., Jadhav, P., Korade, S., \& Teli, P. (2015). Implementing Customizable Online Food Ordering System Using Web Based Application. International Journal of Innovative Science, Engineering \& Technology, 2(4), pp 722- 727. 
[7] Chandramouli, D. (2019). Consumer Expectations on Chatbots of Food Delivery Apps. Thinkquest International journal of technology and management, 4.

[8] Chaturvedi, D., \& Karthik, T. (2019). A study on online food ordering companies in India. EPRA International Journal of Multidisciplinary Research, PP- 6.

[9] Chorneukar, M., J. (2014) "Consumer Perception on Electronic Food Ordering”, A report submitted to Pondicherry University.

[10] Dang, A.K, and et al. (2018) "Consumer Preference and Attitude Regarding Online Food Products in Hanoi, Vietnam" International Journal of Environment Research and Public Health, 14 May, 2018.

[11] Das, J. (2018). Consumer perception towards' online food ordering and delivery services': An empirical study. Journal of Management, PP- 9.

[12] Department, S. R. (2020, Febuary 11). Statista. Retrieved from Tecnology \& Telecommunication: https://www.statista.com/topics/4600/smartphone-market-in-india.

[13] Ebneter, D. S., Latner, J. D., \& Nigg, C. R. (2013). Is less always more? The effects of low-fat labeling and caloric information on food intake, calorie estimates, taste preference, and health attributions. Appetite, 68, 92-97. https://doi.org/10.1016/j.appet.2013.04.023.

[14] Eservices Report 2018 - Online Food Delivery: Statista Digital Market Outlook - Segment Repo [EBook] (p. 14). Eservices Report 2018 - Online Food Delivery.

[15] Eric K. (May, 2015) “A secular shift to Online Food Ordering- Mobile/ online ordering vs Offline ordering”, Techcrunch. Retrieved from https:/techcrunch.com/2015/05/07/a-secularshift-to-online-food-ordering/

[16] Gronroos, C. (1984), "A Service Quality Model and its Marketing Implications", European Journal of Marketing, Vol. 18 No. 4, pp. 36-44. https://doi.org/10.1108/EUM0000000004784

[17] Hong, L, W. (2016), "Food Ordering System Using Mobile Phone”, A report submitted to BIS (Hons) Information Systems Engineering. Faculty of Information and Communication Technology (Perak Campus), UTAR.

[18] Hannu, Lassi, and Mika (2014) "From selling to supporting - Leveraging mobile services in the context of food retailing", Journal of Retailing and Consumer Services, Volume 21, Issue 1, January 2014, Pages 26-36.

[19] Huam, H., Min, S. - S., Ai - Chin, T., Rasli, A., \& Hamid A. B. (2011). Consumers' purchase intentions in fast food restaurants: An empirical study on undergraduate students. International Journal of Business and Social Science, 2 (5), 214 - 221.

[20] Hyde, A.M., Jain, D., Verma, S.K. \& Jain, A. (2017). A Study of Exploratory Buying Behavior Tendencies in FMCG Sector. International Journal on Recent Trends in Business and Tourism (IJRTBT), 1(2), pp 16-27.

[21] IANS (2020), "India's online food delivery industry to touch $\$ 8$ bn mark by 2022: Report". Business Standard, January 28, 2020. Retrieved from https://www.businessstandard.com/article/current-affairs/india-s-online-food-delivery-industry-to-touch-8bn-mark-by-2022-report-120012800822_1.html. 
[22] India's food market size to reach Rs 42 lakh crore by 2020, says Boston Consulting Group. (2015, January 14). The Economic Times. Retrieved from https:/economictimes.indiatimes.com/industry/cons-products/food/indias-foodmarket-size-to-reach-rs-42-lakh-crore-by-2020-says-boston-consultinggroup/articleshow/45890613.

[23] Jayadevan, G., Natarajan, T., \& Chandrasekar, K. (2019). Digital Food Delivery Apps Revolutionizing Food Products Marketing in India. International Journal Of Recent Technology And Engineering, 8(2S6), 662-665. doi:

10.35940/ijrte.b1126.0782s619.cms

[24] Jon,R. (Feb, 2015) "Restaurant Discovery Site Zomato to launch food delivery service, starting in India", Techcrunch.

[25] Kau, A., Tang, Y., \& Ghose, S. (2003). Typology of online shoppers. Journal of Consumer Marketing, 20 (2), 139-156.

[26] Kashyap, K. (2017). The food delivery aps that are competing to get market share in India. The little black book of Billionaire secrets. Retrieved from https://www.ijltemas.in/DigitalLibrary/Vol.7Issue4/110-115.pdf.

[27] Maheshwari, A. and et al. (2016), “India's Food service industry: Growth Recipe. Consumer Markets.KPMG.

[28] Online Food Delivery - India | Statista Market Forecast. (2020). Retrieved 6 January 2020, from https://www.statista.com/outlook/374/119/online-food-delivery/india.

[29] Online Food Delivery - United States | Statista Market Forecast. (2019). Retrieved 2019, from https://www.statista.com/outlook/374/online-food-delivery.

[30] Panse, D., Rastogi, D., Sharma, D., \& Dorji, D. (2019). Understanding consumer behaviour towards utilization of online food delivery Platforms. Journal of Theoretical and Applied Information Technology, PP- 13.

[31] PTI (2017), "Indian online food delivery industry grew $150 \%$ in 2016: report". Times of India, Feb 9, 2017. Retrieved from https://economictimes.indiatimes.com/industry/consproducts/food/indian-online-food report/articleshow/57000685.cms?from $=\mathrm{mdr}$ -delivery-industry-grew-150-in-2016-

[32] PTI (Jan, 2015) “India's food market size to reach Rs. 42 lakh crore by 2020, says Boston Consulting Group", The Economic Times, Business News, Industry- Food.

[33] Prabhash, A. (2020). The consumer perception on online food delivery system among youth in kerala. Epra International Journal of Multidisciplinary Research (IJMR) - Peer Reviewed Journal, 6(2), 96-98. doi: 10.36713/epra2013

[34] Prakasha, R. (2014). Analysis of consumers' perception towards E-retailing- A study in Belthangadi Taluk. Retrieved from http://www.sdmcujire.in/userfiles/MRP/MRP_final_dharmaraj.pdf

[35] Shinde, R., Thakare, P., Dhomne, N., \& Sarkar, S. (2014). Design and Implementation of Digital Dining in Restaurants using Android. International Journal of Advance Research in Computer Science and Management Studies, 2(1), pp 379384. 
[36] Srivastava, A.(2020) "Fine-dining chains smell the money in delivery- only brand" Economic Times Bureau, NewzBuzz, January 14,2020.Retrieved from https://economictimes.indiatimes.com/small-biz/startups/newsbuzz/fine-dining-chains -smell-the-money-in-delivery-only brand/articleshow/73237403.cms?from=mdr.

[37] Singh, R. (2017) “The resurgence of India's Fast Food Delivery”, Economic Times Bureau, ET Prime, December 17, 2017. Retrieved from https://economictimes.indiatimes.com/industry/services/hotels-/-restaurants/theresurgence -of-indias-fast-food-industry/articleshow/62098915.cms?from=mdr

[38] Srinivasan, S. (2018) "India's online food aggregators are taking lessons from China" Economic Times Bureau, NewzBuzz, April 13, 2018. Retrieved from https://economictimes.indiatimes.com/small-biz/startups/newsbuzz/indias-online-foodaggregators-are-taking-lessons-from-china/articleshow $/ 63740650 . \mathrm{cms}$

[39] Wani, H. P., Sarode, N. (2017): "To Identify Measures Undertaken to Prevent the Attrition Rate in the QSR" International Journal of Informative \& Futuristic Research (ISSN: 2347-1697), Vol. 4 No. (7), March 2017, pp. 6778-6785, Paper ID:IJIFR/V4/E7/049.

[40] Wang. L., Tuyen T., Ty N. (2014). Analysing factors to improve service quality of local specialties restaurants: A comparison with fast food with fast food restaurants in Southern Vietnam. Journal of Asian Economic and Social Society, 4 (11), 1592-1606.

[41] Warsi, K.A., \& Nisa, S. (2005). Food Retailing: Fast Food Industry. SSRN Electronic Journal.

[42] Tanpure, S. S., Shidankar, P., \& Joshi, M. (2013). Automated food ordering system with realtime customer feedback. International Journal of Advanced Research in Computer Science and Software Engineering, 3 (2), 220 - 225. 